\title{
Allergic Aspects of IgG4-Related Disease: Implications for Pathogenesis and Therapy
}

\author{
Despina Michailidou ${ }^{1 *}$, Daniella Muallem Schwartz ${ }^{2}$, Tomas Mustelin ${ }^{1}$ \\ and Grant C. Hughes ${ }^{1}$
}

1 Division of Rheumatology, University of Washington, Seattle, WA, United States, ${ }^{2}$ National Institute of Allergy and Infectious Diseases, National Institutes of Health, Bethesda, MD, United States

IgG4-related disease (IgG4-RD) is a rare systemic fibroinflammatory disease frequently associated with allergy. The pathogenesis of IgG4-RD is poorly understood, and effective therapies are limited. However, IgG4-RD appears to involve some of the same pathogenic

OPEN ACCESS

Edited by:

Steven O'Reilly,

Durham University,

United Kingdom

Reviewed by:

lago Pinal-Fernandez,

National Institute of Arthritis and

Musculoskeletal and Skin Diseases

(NIAMS), United States

Carlo Chizzolini,

Université de Genève,

Switzerland

*Correspondence:

Despina Michailidou

de.michailidou@gmail.com

Specialty section:

This article was submitted to

Autoimmune and

Autoinflammatory Disorders,

a section of the journal

Frontiers in Immunology

Received: 10 April 2021

Accepted: 03 June 2021

Published: 07 July 2021

Citation:

Michailidou D, Schwartz DM, Mustelin T and Hughes GC (2021)

Allergic Aspects of IgG4-Related

Disease: Implications for

Pathogenesis and Therapy.

Front. Immunol. 12:693192. doi: 10.3389/fimmu.2021.693192 mechanisms observed in allergic disease, such as T helper 2 (Th2) and regulatory T cell (Treg) activation, IgG4 and IgE hypersecretion, and blood/tissue eosinophilia. In addition, IgG4-RD tissue fibrosis appears to involve activation of basophils and mast cells and their release of alarmins and cytokines. In this article, we review allergy-like features of IgG4-RD and highlight targeted therapies for allergy that have potential in treating patients with lgG4-RD.

Keywords: IgG4-related disease, type 2 immmune response, allergy, eosinophils, basophils, mast cells, alarmins

\section{INTRODUCTION}

IgG4-related disease (IgG4-RD) is a rare, potentially life-threatening fibro-inflammatory disease of unknown etiology. IgG4-RD is clinically characterized by the presence of fibro-inflammatory masses in various organs, dense lymphoplasmacytic infiltration of IgG4-postitive plasma cells, storiform fibrosis and elevated serum levels of $\operatorname{IgG} 4(1,2)$. Although abnormal adaptive immune responses are thought to play a major role in the development of IgG4-RD, the specific mechanisms are incompletely understood. Of note, IgG4-RD patients often suffer from allergic diseases such as asthma, rhinosinusitis, rhinoconjunctivitis or skin diseases such as atopic dermatitis (3-5).

Allergy describes an abnormal adaptive immune response to foreign antigen (allergen). Allergens are an important driver of Type 2 immune responses, which likely evolved in response to helminth infections (6). The hallmark of clinical allergy is the development of allergen-reactive $\mathrm{T}$ helper 2 (Th2) cells, which produce Type 2 cytokines (IL-4, IL-5, IL-13) that promote Ig isotype switch in B cells. This results in production of allergen-specific IgE, which then activates mast cells and basophils to release Type 2 cytokines and preformed inflammatory mediators (7). Allergic inflammation can also be driven by epithelial-derived alarmins like thymic stromal lymphopoeitin (TSLP) and IL-33, which trigger allergen-independent production of Type 2 cytokines (8-12). These cytokines recruit effectors like mast cells, basophils, type 2 innate lymphoid (ILC-2) cells and eosinophils $(13,14)$. Type 2 effectors perpetuate the allergic inflammatory response and ultimately promote tissue damage. For example, IL-5 is particularly important for eosinophil activation, whereas IL-13 drives airway fibrosis (15). 
IgG4-RD and allergic disorders share certain immunopathologic features, such as activation of Th2-like pathways, elevated IgE and IgG4 production, peripheral blood eosinophilia, and tissue mast cell infiltration $(5,16,17)$. Importantly, clinical and epidemiologic evidence suggests that IgG4-RD and allergic entities are not manifestations of a single disease but rather distinct disease processes that both involve type 2 immune activation (18-20), overproduction of pro-Th2 cytokines, and the development of IgE- and IgG4-secreting B cells $(21,22)$. The pathogenesis of IgG4-RD remains unknown, and effective medical therapies are limited. In this review article, we discuss shared etiopathogenetic mechanisms and clinical associations of IgG4-RD with allergic diseases. We then explore potential implications for diagnosis and management of patients with IgG4-RD.

\section{IMMUNO-PATHOPHYSIOLOGICAL MECHANISMS IN IgG4-RD}

The pathogenesis of IgG4-RD is not yet fully understood, but it is thought to involve varied mechanisms including autoimmunityassociated and allergy-associated factors (Table 1). Patients with IgG4-RD classically have oligoclonal expansion of both $\mathrm{B}$ and $\mathrm{T}$ cells in the peripheral blood, with oligoclonally expanded CD4+ T lymphocytes in the affected tissues (23). CD4+ T lymphocytes expressing CD40 ligand (CD40L) drive differentiation of plasmablasts, germinal center formation (GC), and production of IgG4 (24). A population of effector memory CD4+ T cells with a cytotoxic function (CD4+ CTLs) has also been described in IgG4-RD and it is possible that arises from chronic antigenic stimulation. An antigen-driven process that requisites an interaction between CD4+CTLs and activated B cells that serve as antigen presenting cells might be implicated given the significant reduction of circulating CD4+CTLs and plasmablasts after glucorticoid therapy (Figure 1) (25). CD4 +CTLs also express IL-6, TGF- $\beta$, and IFN- $\gamma$, which may contribute to chronic inflammation and fibrosis in IgG4-RD $(26,27)$. On the other hand, patients with severe asthma have reduced IFN- $\gamma$ production, which promotes differentiation of CD4+T-cells into Th2 cells (28) (Table 1).

Both memory and follicular CD4+ T helper cells are thought to contribute to IgG4-RD via secretion of profibrotic cytokines (e.g., IL-6, IFN- $\gamma$ and TGF- $\beta$ ), induction of IgG4 class-switching, expansion of plasmablasts, and production of autoantibodies (4). $\mathrm{T}$ follicular helper ( $\mathrm{Tfh}$ ) cells have a particularly important role in allergy by promoting isotype switching to IgE via secretion of IL-4 (29) and in IgG4-RD by contributing to isotype class switching and promoting ectopic GC formation through IL-21 production (Figure 1 and Table 1) $(23,30)$. IL-21 combines with T regulatory cell (Treg)-derived IL-10 and myeloid-derived IL-12 to promote IgG4 production (31-33). IL-10 has been specifically described as a key cytokine that promotes the differentiation of IgG4-switched B cells to IgG4-secreting plasma cells (34) (Figure 1). IL-10 production can be enhanced by IL-27 by converting activated inflammatory CD4+T cells into IL-10 producing Treg cells (35). Immunohistochemically CD4+CD25 +Foxp3+Treg cells were more frequently found to infiltrate lesions in autoimmune pancreato-cholangitis compared to primary sclerosing cholangitis and primary biliary cirrhosis, and produced more IL-10 and TGF- $\beta$ as determined by RTPCR (18). Massive expansion of polyclonal IgG4-switched B and/or plasma cells appears to drive tissue infiltration and organ damage in IgG4-RD (36). Activation of B cells in GCs results in production of B cells with high-affinity antigen receptors, and in generation of plasmablasts. It is possible that these plasmablasts induce activation of $\mathrm{CD} 4+\mathrm{T}$ cells and result in secretion of cytokines, such as IL-1, TGF $\beta 1$, IFN- $\gamma$ and other signaling mediators of the innate and adaptive immunity driving the fibrotic pathology in igG4-RD $(37,38)$ (Table 1 ).

These B cell subsets express CD20, so this is perhaps why B cell depletion with the anti-CD20 monoclonal antibody rituximab is effective for many forms of IgG4-RD (39). The mechanisms of action appear to include depletion of antigenpresenting $\mathrm{B}$ cells, subsequent reduction in activation of pathogenic CD4+ T cells and their release of inflammatory and profibrotic cytokines (4). Response to rituximab therapy correlates with reduction in frequency of distinct circulating plasmablast clones; and relapse corresponds with their return. This suggests that relapse after B cell depletion involves recruitment and activation of naïve $B$ cells and/or reemergence of memory B cells resistant to rituximab (40).

\section{TYPE 2 IMMUNITY IN IgG4-RD}

Amongst the factors thought to contribute to IgG4-RD, Type 2 immunity has been proposed to play a significant role in disease pathogenesis. This includes the hallmark Type 2 immunoglobulin IgE, effector cells such as mast cells and Th2 cells, and cytokines/chemokines. Much of the data suggesting a role for Type 2 factors in IgG4-RD are observational, and a direct mechanistic link has not yet been established for these factors. Additionally, it is important to note that Type 2 factors are not the only contributors to IgG4-RD pathogenesis and that other factors including IFN- $\gamma$ and IgG1 are also likely to have an important role (Table 1). However, the large amount of data demonstrating the presence of Type 2 factors in the circulation and tissue of IgG4-RD patients, and the correlation of these factors with clinical features, suggest that Type 2 immunity has a role in IgG4-RD.

\section{The Role of IgE in IgG4-RD}

Allergen-specific IgE is a major mediator of clinical allergy, and other types of IgE such as autoreactive IgE are known to play important roles in the development of certain autoimmune diseases $(41,42)$. IgE sensitizes mast cells to release histamine and prostaglandins in an antigen-specific manner in allergic diseases (43) (Table 1). In parallel to the IgE response, there is also production of high levels of allergen-specific IgG4 antibodies the potential role of which has not yet been clearly established in allergy (44). A recent study showed that there was 
TABLE 1 | Mediators of innate and adaptive immunity in IgG4-RD and allergic disorders.

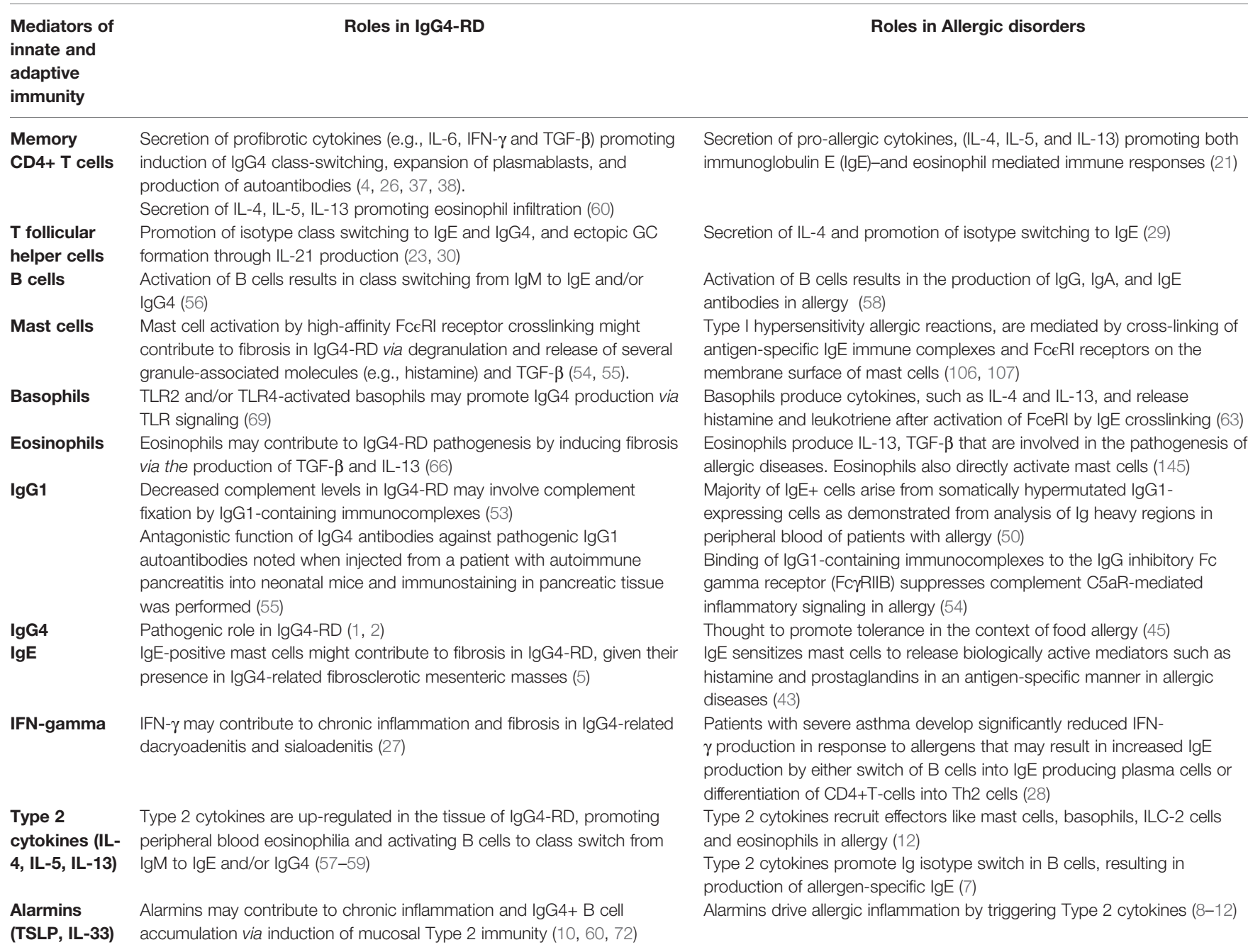

IL-6, interleukin 6; IFN- $\gamma$, interferon gamma; TGF- $\beta$, tumor growth factor beta; IL-4, interleukin 4; IL-5, interleukin 5; IL-13, interleukin 13; GC, germinal center; IL-21, interleukin 21; IgE, immunoglobulin E; IgM, immunoglobulin M; IgG4, immunoglobulin G subtype 4; IgA, immunoglobulin A; TLR, toll like receptor; FCᄀRIIB, FC gamma receptor IIB; C5aR, complement 5a receptor; ILC-2, type 2 innate lymphoid cells; IgG4-RD, IgG4-related disease; TSLP, thymic stromal lymphopoeitin; IL-33, interleukin 33; Th2, Thelper 2 cells.

a higher overlap between IgE and IgG4 cow milk (CM) epitopes in patients tolerating CM compared to those who reacted to it, suggesting a blocking role of IgG4 and the importance of balance between IgE and IgG4 in tolerance (45).

IgE may also play a major role in IgG4-RD, as a significant correlation between serum IgE and IgG4 levels has been observed in patients with concurrent diagnoses of IgG4-related Type 1 autoimmune pancreatitis and clinical allergy (46). In the context of clinical allergy, repeated exposure to certain allergens promote a "modified allergy" milieu in which Th2-derived IL-4 and Tregderived IL-10 combine to induce IgG4 production (47). It remains to be determined whether these mechanisms underlie IgG4-dominant responses in IgG4-RD, and how other IgG4promoting cytokines like IL-21 may contribute (Table 1). This is in part because there is a paucity of information about Ig levels before onset of IgG4-RD.

The exact source of the elevated IgG4 and IgE in the blood and tissue in IgG4-RD patients is unknown. Tissue IgE-positive memory B cells and plasma cells may emerge directly from a germinal center or through indirect class switching from other intermediate antibody isotypes such as $\operatorname{IgG1}$ to $\operatorname{IgG} 4(48,49)$. Looney et al. found evidence that the majority of IgE+ cells derive from somatically hypermutated IgG1-expressing cells as demonstrated from analysis of Ig heavy regions in peripheral blood of patients with allergy and indirect isotype switching from IgG4 to IgE contributes to the IgE pool (50) (Table 1). In addition, IgG4+ B cells may bind IgE molecules via their lowaffinity FceRII receptors (51). The importance of this observation remains to be determined but suggests integration of $\operatorname{IgE}$ and IgG4 responses at the $\mathrm{B}$ cell level. Moreover, mast cells infiltrating IgG4-RD tissue show strong cytoplasmic staining for IgE via its binding to the high-affinity IgE receptor (FceRI) $(52,53)$. IgE-positive mast cells may contribute to fibrosis in IgG4-RD, which is supported by their presence in an IgG4related fibrosclerotic mesenteric masses; in these cases, serum IgE levels could be a useful biomarker in diagnosis and 


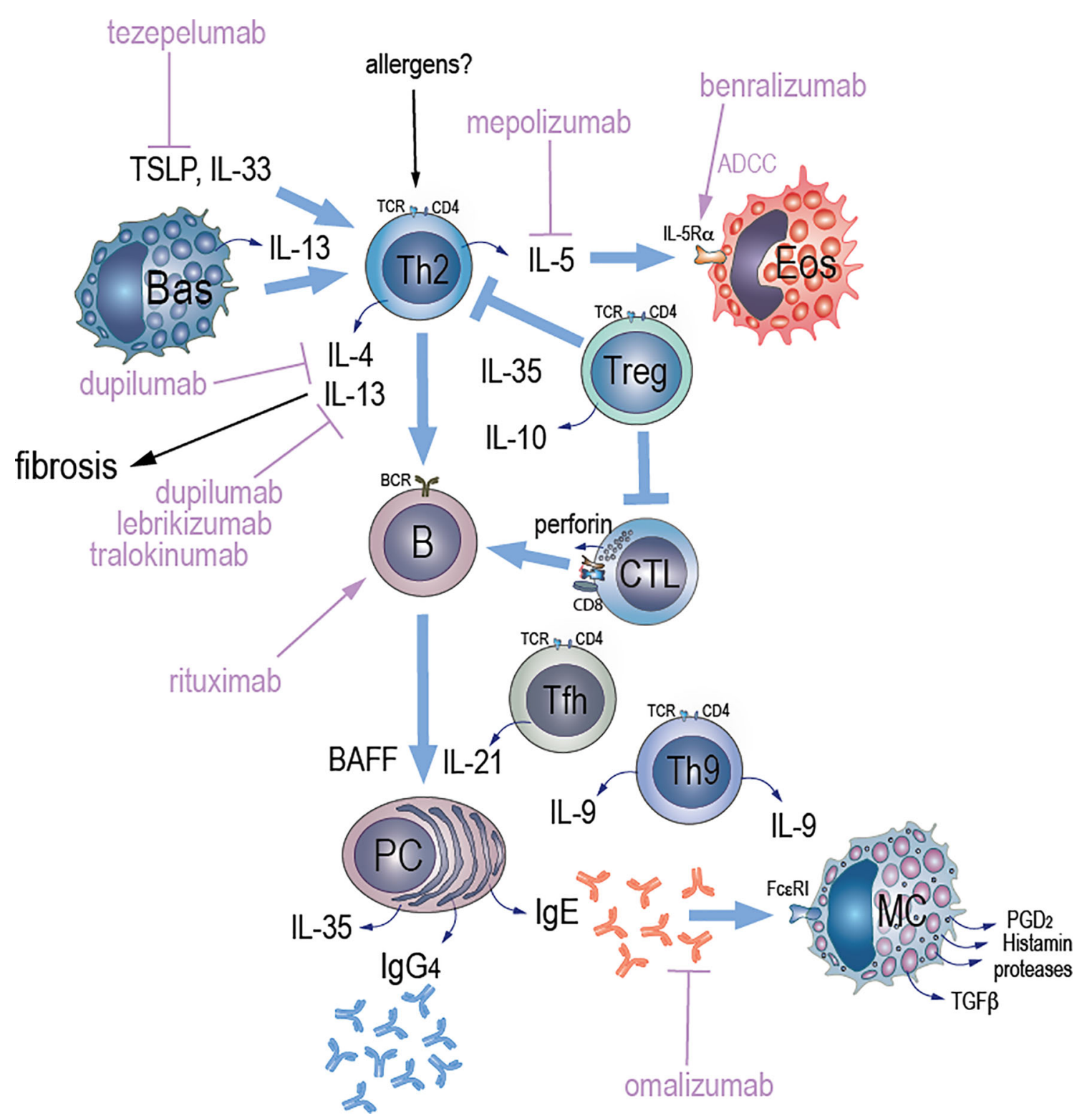

FIGURE 1 | Potential mechanisms of Type 2 immunity and therapeutic targets in IgG4-RD. We hypothesize that an unknown antigenic stimulus (allergen) triggers Th2 cells and activates them to secrete interleukins. Activation of Th2 cells by TSLP promotes secretion of IL-4, IL-5, and IL-13, which activate B cells and eosinophils. Both TSLP and IL-33 may contribute to IgG4 accumulation via induction of a Th2 cytokine environment. TLR-activated basophils secrete BAFF and IL13. BAFF that is also secreted from B cells promotes immunoglobulin class switching while IL-13 maintains Th2 cell-dominant immune responses contributing to increased lgG4 production. A population of effector memory CD4+ T cells with a cytotoxic function (CD4+ CTLs) that arises from chronic antigenic stimulation has also been described in IgG4-RD. An antigen-driven process that requires an interaction between CD4+ CTLs and activated B cells that serve as antigen presenting cells might be implicated in the pathogenesis of igG4-RD based on observations of significant reduction of circulating CD4+CTLs and plasmablasts after glucorticoid therapy or B cell depletion with rituximab through antibody-dependent cell-mediated cytotoxicity (ADCC). Other key players in the pathogenesis of IgG4-RD include follicular CD+T helper (Tfh) cells that induce lgG4 class-switching, expansion of plasmablasts, and production of autoantibodies. Thh cells drive immunoglobulin class switching and promote ectopic GC formation through IL-21 production. IL-10 that is secreted by T regulatory (Treg) cells drives the differentiation of IgG4-classswitching B cells to lgG4-secreting plasma cells, whereas IL-35 may suppress inflammation via activation of effector Tregs and suppression of CD4+CTLs. Plasma cell derived IL-35 may also drive the differentiation of naïv CD4 T cells towards a Th9 phenotype, and IL-9 release, which further promotes plasma cell differentiation and IgG4 immunoglobulin class switching. IgE secreted by plasma cells stimulates mast cells via its binding to the high-affinity lgE receptor (FcERI) leading to release of granule contents and cytokines, which together drive collagen production and fibrosis. Targeting of TSLP-mediated signaling pathway with tezepelumab, and resultant abrogation of Th2 cascades, might be one of potential therapeutic options in IgG4-RD. Blocking both IL-4 and IL-13 signaling pathways with dupilumab might reduce inflammation and fibrosis in igG4-RD. Blockage of IL-13 signaling pathway that is implicated in Th2-related fibrosis with either lebrikizumab or tralokinumab might be another attractive therapeutic target in igG4-RD. Depletion of IL-5R-expressing eosinophils through ADCC with benralizumab or blockage of IL-5 with mepolizumab might reduce eosinophilia and could be an alternative therapeutic targets in patients with IgG4-RD that have peripheral or tissue eosinophilia. Dissociation of pre-bound lgE from FcERI with omalizumab might reduce activation of mast cells and production of TGF- $\beta 1$ that induces fibrosis. 
prediction of disease relapse (5). Activation of mast cells by highaffinity FceRI receptor crosslinking might contribute to fibrosis in IgG4-RD via degranulation and release of several granuleassociated molecules (e.g., histamine) and TGF- $\beta$, that together may drive fibroblast activation, collagen production, and tissue fibrosis (54, 55), (Table 1 and Figure 1). However, the precise role of mast cells in IgG4-RD tissue fibrosis remains to be determined.

\section{Type 2 Immune Effector Cells in IgG4-RD}

Although IgE is a hallmark of clinical allergy, Th2 cells and their associated cytokines are considered major drivers of Type 2 immune responses (56). It is thought that in IgG4-RD these Th2 cytokines promote peripheral blood eosinophilia and activate B cells to class switch from IgM to IgE and/or IgG4, as they do in allergic diseases (57-59) (Table 1 and Figure 1). Indeed, in the peripheral blood and involved tissues of patients with IgG4related dacryoadenitis and sialadenitis, there was a significant increase in stimulation expressed gene 2 (ST2) memory-positive Th2 cells that were characterized by high IL-5 expression (60). Moreover, the Th2 cytokines IL-4, IL-5, and IL-13 were found to be up-regulated in the tissue of IgG4-related sclerosing pancreatitis and cholangitis (18). Thus, chronic Th2 activation may contribute to IgG4-RD-associated tissue phenotypes such as eosinophil infiltration and fibrosis (61).

Effector cells like eosinophils and basophils also can directly mediate type 2 immune responses $(62,63)$. These cells are generally recruited by and expand in response to Type 2 cytokines like IL-5, although in some Type 2 immune syndromes they are constitutively dysregulated (64). Eosinophilia has been described in patients with IgG4-RD with or without allergy (65). Eosinophils may contribute to IgG4-RD pathogenesis by inducing fibrosis via the production of TGF- $\beta$ and IL-13 (66) (Table 1).

Basophils are Type 2 effectors that both respond to and promote Th2-mediated inflammation (63). Toll like receptor (TLR) activation of basophils from patients with IgG4-RD led to release of B-cell-activating factor (BAFF) and IL-13, enhancing IgG4 production by B-cells from healthy controls (67). BAFF promotes immunoglobulin class switching, whereas IL-13 maintains Th2-cell dominant immune responses (68) (Figure 1). Thus, activated basophils may induce IgG4 production via TLR signaling (69) (Table 1). The specific TLR ligands that activate basophils in IgG4-RD patients are unknown.

\section{Type 2 Cytokines and Chemokines in lgG4-RD}

In addition to Type 2 cytokines like IL- 4 and IL-13, Type 2 immune responses can also be induced by alarmins, which are epithelial-derived immune activating proteins released in response to cellular stress, injury, or death (70). IL-33 and thymic stromal lymphopoietin (TSLP) are two alarmins that are critical for promoting acute Type 2 immune responses at barrier surfaces (71). Both TSLP and IL-33 were found to be upregulated in the submandibular glands of patients with IgG4-RD; these alarmins may contribute to chronic inflammation and
IgG4+ B cell accumulation via induction of mucosal Type 2 immunity $(10,60,72)$.

Type 2 chemokines such as thymus and activation-regulated chemokine (TARC) can also be important mediators of allergic disease (73). TARC is a ligand for the $\mathrm{C}-\mathrm{C}$ chemokine receptors CCR4 and CCR8, which are predominantly expressed by Th2 cells (74). High serum levels of TARC were observed in patients with IgG4-RD. TARC levels did not correlate with blood IgG4 levels or peripheral eosinophil counts, but correlated positively with multiple organ involvement and could be a new therapeutic target of IgG4-RD (75).

IL-35, a cytokine of the IL-12 family appears to suppress airway inflammation in asthma $(76,77)$. The role of IL-35 in IgG4-RD remains unclear, as potentially it could play protective or pathogenic roles. For example, both plasma and pancreatic tissue levels of IL-35 were elevated in IgG4-related type 1 autoimmune pancreatitis (AIP) and appeared to suppress inflammation via activation of effector Tregs and suppression of Th2 immune responses (78). However, in another study, IL-35 was found to be secreted by IgG4-positive plasma cells in the plasma of patients with hepatobiliary and/or pancreatic involvement of IgG4-RD, driving the differentiation of naïve CD4 T cells towards Th9 cells via an interferon regulatory factor 4 (IRF4) signaling pathway. This differentiation led to secretion of IL-9 from Th9 cells that promoted plasma cell differentiation and immunoglobulin class switch towards IgG4 (79). IL-9 is also known to up regulate mast cell IgE receptor expression, leading to increased IgE production and inducing eosinophil growth (80) (Figure 1). Thus, IL-35 might contribute to an important amplification loop in IgG4-RD that could make it a potential therapeutic target in IgG4-RD.

\section{Genetic Overlap of IgG4-RD With Type 2 Immunity}

The genetic landscape of IgG4-RD is not well explored. Genetic studies of IgG4-RD identified two susceptibility loci, the human leukocyte antigen (HLA)-DRB1 and Fc gamma receptor 2B (FCGR2B) (81). Interestingly, the HLA-DRB1 risk allele was also associated with peanut allergy, consistent with the idea of shared immunopathogenesis between allergy and IgG4-RD (82). In addition, a functional single nucleotide polymorphism (SNP) in the inhibitory FCGR2B was found to be associated with atopy and increased IgE production, suggesting that FCGR2B SNP may have a role in allergy and IgG4-RD via its effects on IgE production (83).

\section{ALLERGIC AND TYPE 2 IMMUNE CONDITIONS ASSOCIATED WITH IgG4-RD}

\section{Association of IgG4-RD With Asthma and Allergic Rhinitis}

A cross-sectional study of 114 patients with IgG4-RD showed that $19 \%$ had been previously diagnosed with allergic diseases, including allergic rhinitis, sinusitis, or bronchial asthma (84). 
In a retrospective study of 64 patients with IgG4-RD, the prevalence of allergic rhinitis was significantly higher compared to that in patients with Sjogren's syndrome (26\% vs $2 \%, \mathrm{p}<0.001)(85)$. In another retrospective observational study of 31 patients with orbital IgG4-RD, asthma was found in $52 \%$ (86). A case of IgG4-RD with bronchial asthma was also reported (87). Adult onset asthma and periocular xanthogranuloma (AAPOX) is a rare non-Langerhans histiocytosis characterized by periocular infiltration of foamy histiocytes, Touton giant cells, and benign hyperplasia with plasma cell infiltration in eyelids or lymph nodes. A rare variant of IgG4-RD characterized by eyelid xanthelasmas and adult-onset asthma with salivary and lacrimal glands enlargement has also been reported in the literature $(88,89)$.

Several observations indicate a link between IgE, IgG4 and eosinophil levels in patients with severe allergic airway disease. In a recent study of patients with difficult-to-treat asthma, elevated blood IgG4 levels were associated with higher blood IgE and eosinophil levels (90). In the same study, allergic bronchopulmonary aspergillosis (ABPA) or eosinophilic granulomatosis with polyangiitis (EGPA) were more frequently diagnosed in patients with elevated serum IgG4 compared to the control group with normal IgG4 levels. Moreover, anti-Aspergillus fumigatus IgG4-antibodies were found in cystic fibrosis patients with ABPA (91). Thus, prominent IgG4 production appears to be a feature of both IgG4-RD and severe allergic airway disease.

\section{Association of IgG4-RD With Chronic Rhino-Sinusitis}

In a recent study of IgG4-RD patients, those with chronic rhinosinusitis (CRS) (30/46 or $65.2 \%)$ were more prone to allergic manifestations (asthma, drug allergy or allergic skin conditions) and more often had eosinophilia compared to patients without CRS (92). IgG4-related CRS is considered a specific disease entity, despite lack of consensus regarding classification/diagnostic criteria. Unlike typical CRS, IgG4-related CRS can present with bony and soft tissue invasion (93-95). Piao et al. reported that the number of IgG4positive plasma cells/high power field (HPF) in nasal mucosa biopsies from IgG4-related CRS patients was significantly higher than in nasal biopsies from patient with granulomatosis with polyangitis (GPA) or Rosai-Dorfman disease (RDD), but not patients with fungal rhinosinusitis (FRS). In the same study, the ratio of IgG4/IgG-positive plasmacytes in nasal mucosa biopsies was $>40 \%$ in $90 \%$ of IgG4-related CRS patients compared to only $10 \%$ of GPA patients, $20 \%$ of RDD patients, and $20 \%$ of FRS patients. Thus, while IgG4+ B cell infiltration is prominent in IgG4-related CRS, it is also observed in other conditions of chronic upper airway inflammation (96). There are also reported cases of isolated paranasal IgG4-RD causing destructive disease $(97,98)$ and periorbital IgG4-RD occurring with aspirin-exacerbated respiratory disease (AERD) (99).

\section{Association of IgG4-RD With Eosinophilic Granulomatosis With Polyangiitis}

Eosinophilic granulomatosis with polyangiitis (EGPA) is a necrotizing vasculitis of small to medium-sized vessels associated with asthma, eosinophilia, paranasal sinusitis, pulmonary infiltrates and mononeuritis multiplex (100). Elevated serum IgG4 levels have been reported in patients with EGPA (101-103). A case of EGPA complicated by chronic symmetrical dacryoadenitis suggesting Mikulicz's disease (a form of IgG4-RD) was also reported (104). Overall, the observations suggest shared immunopathology in EGPA and IgG4-RD.

\section{Association of IgG4-RD With Hypocomplementemic Urticarial Vasculitis}

Mast cells are key effector cells in urticaria and many cases of angioedema (105). Histamine release from human mast cells, triggered by cross-linking of specific bound IgE to the high affinity IgE receptor, $F c \in R 1$, is central to histamine-induced angioedema - a disorder that belongs to the spectrum of Type 2 immune diseases $(106,107)$ (Table 1). Hypocomplementemic urticarial vasculitis (HUV) is an immune-complex mediated disorder associated with urticaria and leukocytoclastic vasculitis, angioedema, arthritis, and recurrent abdominal pain (108). One proposed mechanism for urticaria and angioedema in HUV involves the formation of immune complexes, subsequent activation of the classical complement system, and generation of anaphylotoxins (e.g., C3a and C5a) that cause mast cell degranulation and histamine release (109).

High levels of serum IgG4 and an elevated IgG4/total IgG ratio were observed in one patient with typical HUV (110). Takao et al. reported a case of HUV with organ manifestations suggestive of IgG4-RD, including interstitial nephritis, and submandibular and inguinal lymphadenopathy with 40\% IgG4expressing B cells (111).

\section{TYPE 2 IMMUNITY VS. ALLERGY IN IgG4-RD}

Even though Type 2 immune responses and allergy are observed in patients with IgG4-RD, they are not necessarily always linked mechanistically (112). Indeed, non-type 2 factors such as IgG1 immunocomplexes and complement activation system have also a role in both allergy and IgG4-RD (113-115) (Table 1). For example, asthma and chronic rhinitis can be caused by neutrophil- driven inflammation $(116,117)$, which may underlie the high prevalence of rhinosinusitis in patients with certain autoinflammatory diseases $(118,119)$. Another example is the association of inflammasome activation with eczema (120). These examples raise the possibility that allergy-associated phenotypes in IgG4-RD may be due to non-Type 2 immune responses but rather other types of signaling pathways.

Peripheral eosinophilia and elevated serum IgE levels have been reported along with history of allergies and atopic symptoms in $40 \%$ of patients with type I autoimmune pancreatitis, consistent with the hypothesis that allergic mechanisms drive IgG4-RD (121). However, elevated IgE levels and eosinophilia are also present in non-atopic patients with IgG4-RD kidney disease (122). Among patients with IgG4-RD in 
TABLE 2 | Select monoclonal antibodies with therapeutic potential in IgG4-related disease (IgG4-RD).

\begin{tabular}{|c|c|c|c|}
\hline $\mathrm{mAb}$ & Antibody type & Target & Current Indications \\
\hline Dupilumab & Fully human, lgG4 & IL-4R $\alpha$; Inhibits signaling of IL-4 and IL-13 & $\begin{array}{l}\text { Atopic dermatitis }(127,128) \\
\text { Asthma (131) }\end{array}$ \\
\hline Lebrikizumab & Humanized, lgG4 & IL-13; prevents formation of IL-13R $\alpha 1 / \mathrm{IL}-4 \mathrm{R} \alpha$ heterodimer receptor signaling complex & $\begin{array}{l}\text { Asthma (133) } \\
\text { Atopic dermatitis (134) }\end{array}$ \\
\hline Tralokinumab & Fully human, lgG4 & IL-13; prevents binding of IL-13 to IL-13R $\alpha 1$ and IL-13R $\alpha 2$ & $\begin{array}{l}\text { Asthma (136) } \\
\text { Atopic dermatitis (138) }\end{array}$ \\
\hline Omalizumab & Humanized, IgG1 & IgE Fc region & $\begin{array}{l}\text { Asthma (141) } \\
\text { Chronic urticaria (141) } \\
\text { ABPA (142) } \\
\text { CRS (142) } \\
\text { Atopic dermatitis (142) }\end{array}$ \\
\hline Mepolizumab & Humanized, IgG1 & IL-5 & $\begin{array}{l}\text { Asthma (148) } \\
\text { EGPA (149) }\end{array}$ \\
\hline Benralizumab & Humanized, IgG1 & IL-5R & Eosinophilic Asthma (146) \\
\hline Reslizumab & Humanized, IgG4 & IL-5 & Eosinophilic Asthma (150) \\
\hline Tezepelumab & Fully human & TSLP & Asthma (151) \\
\hline
\end{tabular}

ABPA, allergic bronchopulmonary aspergillosis; CRS, chronic rhinosinusitis, EGPA, eosinophilic granulomatosis with polyangiitis.

another study, the mean IgE concentrations and eosinophil blood counts were similar, regardless of history of atopy (123). Thus, IgG4-RD and allergy both appear to engage similar Type 2 pathways of immune activation, their relationships to each other in terms of pathogenesis remain uncertain.

\section{THERAPEUTIC IMPLICATIONS AND FUTURE DIRECTIONS}

IgG4-RD is thought to result from abnormal activation of both innate and adaptive immunity. IgG4-RD might reflect an individual's propensity towards pathologic Th2 immune responses, as observed in allergic conditions. Thus, like with allergy, targeting signaling pathways that are involved in Th2 immunity could be effective in IgG4-RD (Figure 1 and Table 2).

First-line treatment for IgG4-RD is glucocorticoids. Rituximab and other immunosuppressive agents such as azathioprine, methotrexate or mycophenolate mofetil are recommended in recurrent or refractory disease, but relapses and flares are common even with these agents (124). Multi-organ involvement, peripheral eosinophilia, and high serum levels of IgG4 and IgE at disease onset are predictors of relapse (125). After B cell depletion with rituximab, relapses may occur in more than $50 \%$ of IgG4-RD patients (126). Thus, there is a pressing need for more effective and safer therapies for patients with IgG4-RD.

Monoclonal antibodies (mAbs) targeting IL-4Ra, such as dupilumab (127), ameliorate atopic dermatitis by blocking both IL-4 and IL-13 signaling (128). In patients with IgG4-RD, this blockade could reduce inflammation and fibrosis (129). Indeed, dupilumab was able to control inflammation and fibrosis in a patient with both atopic dermatitis and IgG4-RD (130). The use of dupillumab warrants more prospective studies in IgG4-RD. Dupilumab was also recently approved for treatment of moderate to severe asthma both in adolescents and adults (131).
Kasaian et al. created a recombinant bifunctional IL-4/IL-13 antagonist that in a mouse of model of asthma reduced not only IL-4-dependent increase in serum IgE levels but also IL-13dependent airway hyper-responsiveness and lung inflammation (132). Dual IL4/IL-13 antagonists might be particularly effective for treating patients with IgG4-RD and elevated IgE levels and/or concurrent asthma.

Two anti-IL-13 agents, lebrikizumab and tralokinumab, also have potential therapeutic activity in IgG4-RD. Lebrikizumab is a humanized IgG antibody that binds to IL-13, neutralizing its activity and improving lung function in asthma patients (133). It also appeared to be a promising therapy for moderate to severe atopic dermatitis (134). In a recent phase 2 randomized, double blind, placebo controlled trial, lebrikizumab did not show benefit in patients with idiopathic pulmonary fibrosis (IPF), either as monotherapy or in combination with pirfenidone (135). Tralokinumab prevents IL-13 binding to both IL-13R $\alpha 1$ and IL-13R $\alpha 2$, which are considered important mediators of Th2related fibrosis via stimulation and activation of TGF- $\beta 1$ (136, 137). Treatment with tralokinumab successfully improved symptoms in patients with asthma (136) and atopic dermatitis (138). Tralokinumab blockade of IL-13 attenuated lung fibrosis in a humanized mouse model of IPF (139). However, in a phase 2 randomized controlled study, tralokinumab showed no efficacy in patients with IPF (140).

Omalizumab is an anti-IgE $\mathrm{mAb}$ that is approved for severe allergic asthma and chronic urticaria (141). There have been many reports of off-label uses of omalizumab in diseases where IgE might have a pathogenic role, such as allergic rhinitis, ABPA, anaphylaxis, angioedema, non-atopic asthma, atopic dermatitis, EGPA, and CRS (142). By dissociated pre-bound IgE from FceRI, omalizumab reduces activation of mast cells and basophils (143) - a suspected mechanism of fibrosis in IgG4$\mathrm{RD}$. While omalizumab has not been evaluated for the treatment of IgG4-RD in clinical trials, it could prove to be an effective therapy, particularly in those with elevated IgE levels (Figure 1). However, in IgG4-associated eosinophilic esophagitis, omalizumab failed to reduce either tissue eosinophils or 
symptoms, despite the frequent presence of $\operatorname{IgE}$ bearing mast cells in esophageal tissues (144). Thus, mast cell/basophil activation may not be central to symptoms in this form of IgG4-RD.

mAbs targeting IL-5 (e.g., mepolizumab and reslizumab) or the IL-5 receptor (IL-5R) (e.g., benralizumab) reduce peripheral eosinophilia (145) and therefore might be effective therapies in IgG4-RD patients with peripheral or tissue eosinophilia. Benralizumab might be particularly effective in this regard, because it both depletes IL-5R-expressing eosinophils (through antibody-dependent cell-mediated cytotoxicity, ADCC) and limits IL-5 signaling in multiple cell types (146). Interestingly, in at least one patient with EGPA, successful treatment with benralizumab also resulted in reduction of serum IgG4 levels (147). Mepolizumab is approved for treatment of severe eosinophilic asthma and EGPA, reducing the number of eosinophils in both the blood and sputum $(148,149)$. Reslizumab is effective in reducing eosinophils in patients with asthma and was recently approved for the management of severe eosinophilic asthma (150).

Tezepelumab is a fully human anti-TSLP mAb that prevents interaction of TSLP with its receptor, thereby inhibiting downstream inflammatory pathways; tezepelumab has been used for the treatment of severe asthma in phase II trials (151). Combined treatment of tezepelumab and subcutaneous cat immunotherapy (SCIT) significantly decreased nasal symptoms in patients during a nasal cat allergen challenge compared to patients who received SCIT and placebo at weeks 25 and 52, but the response was not sustained after therapy was completed (152). Targeting of TSLP-mediated signaling pathway, and resultant abrogation of Th2 cascades, might be another attractive therapeutic strategy to treat IgG4-RD (Figure 1).

\section{CONCLUSIONS}

IgG4-RD is a rare fibro-inflammatory disease of unknown etiology. Although the adaptive arm of the immune response is thought to play a major role in disease pathogenesis, the specific mechanisms are incompletely understood. In this review article, we discuss clinical and mechanistic overlap between IgG4-RD and allergy in order to better understand IgG4-RD and identify therapeutic targets for which approved agents already exist. A

\section{REFERENCES}

1. Stone JH, Khosroshahi A, Deshpande V. IgG4-related Disease. New Engl J Med (2012) 366:539-51. doi: 10.1056/NEJMra1104650

2. Khosroshahi A, Stone J. A Clinical Overview of IgG-4 Related Systemic Disease. Curr Opin Rheumatol (2011) 23(1):57-66. doi: 10.1097/BOR.0b013e3283418057

3. Islam $\mathrm{AD}$, Selmi C, Datta-Mitra A, Sonu R, Chen M, Gershwin ME, et al. The Changing Faces of IgG4-Related Disease: Clinical Manifestations and Pathogenesis. Autoimmun Rev (2015) 14(10):914-22. doi: 10.1016/j.autrev.2015.06.003

4. Della-Torre E, Lanzillotta M, Doglioni C. Immunology of IgG4-Related Disease. Clin Exp Immunol (2015) 181(2):191-206. doi: 10.1111/cei.12641

5. Culver EL, Sadler R, Bateman AC, Makuch M, Cargill T, Ferry B, et al. Increases in IgE, Eosinophils, and Mast Cells, can be Used in Diagnosis and significant subset of patients with IgG4-RD have allergic disease or features of allergy, such as elevated IgE levels, tissue and blood eosinophilia, and infiltration of affected tissues by IgE-primed mast cells. More research into this subset, including genetic studies, is needed to better understand IgG-RD's relationship to allergy.

Recent work in IgG4-RD has identified allergy-like, Th2related pathways of aberrant immune activation that may contribute to tissue inflammation and fibrosis. These include overproduction of molecules involved in Th2 differentiation (IL-13, TSLP, IL-33), generation of IgG4- and IgE-secreting plasma cells (BAFF, IL-4, IL-13), recruitment/activation of tissue eosinophils (IL-5) and mast cells (IL-9), and tissue fibrosis (TGF- $\beta$ ). Thus, targeting one or more of these molecules with drugs currently available for the treatment of allergy may be beneficial in patients with IgG4-RD, for which no specific therapy has yet been proven effective.

\section{AUTHOR CONTRIBUTIONS}

DM, DS, TM, and GH substantially contributed to this review with regards to content and structure of the manuscript. All authors contributed to the article and approved the submitted version.

\section{FUNDING}

DM is supported by Pfizer US Pharmaceuticals Group grant with sponsor award number 53857367. TM is supported by NIH grants R21AR075134, R01 AR074939 and R21 AR077266. DS is funded by NIAID intramural program. The funder bodies were not involved in the study design, collection, analysis, interpretation of data, the writing of this article or the decision to submit it for publication.

\section{ACKNOWLEDGMENTS}

We would like to thank Dr. Christian Lood for reviewing the manuscript and providing us with constructive feedback and suggestions.

to Predict Relapse of IgG4-Related Disease. Clin Gastroenterol Hepatol (2017) 15(9):1444-1452.e6. doi: 10.1016/j.cgh.2017.02.007

6. Galli SJ, Tsai M, Piliponsky AM. The Development of Allergic Inflammation. Nature (2008) 454(7203):445-54. doi: 10.1038/nature07204

7. Ozdemir C, Akdis M, Akdis CA. T-Cell Response to Allergens. Chem Immunol Allergy (2010) 95:22-44. doi: 10.1159/000315936

8. Chan BCL, Lam CWK, Tam LS, Wong CK. Il-33: Roles in Allergic Inflammation and Therapeutic Perspectives. Front Immunol (2019) 10:364. doi: 10.3389/fimmu.2019.00364

9. Shubin NJ, Clauson M, Niino K, Kasprzak V, Tsuha A, Guga E, et al. Thymic Stromal Lymphopoietin Protects in a Model of Airway Damage and Inflammation Via Regulation of Caspase-1 Activity and Apoptosis Inhibition. Mucosal Immunol (2020) 13(4):584-94. doi: 10.1038/s41385-020-0271-0 
10. Capecchi R, Italiani P, Puxeddu I, Pratesi F, Tavoni A, Boraschi D, et al. IL-1 Family Cytokines and Receptors in IgG4-Related Disease. IL-1 Family Cytokines and Receptors in IgG4-Related Disease. Cytokine (2018) 102:145-8. doi: 10.1016/j.cyto.2017.08.001

11. Semlali A, Jacques E, Koussih L, Gounni AS, Chakir J. Thymic Stromal Lymphopoietin-Induced Human Asthmatic Airway Epithelial Cell Proliferation Through an IL-13-Dependent Pathway. J Allergy Clin Immunol (2010) 125(4):844-50. doi: 10.1016/j.jaci.2010.01.044

12. Tatsuno K, Fujiyama T, Yamaguchi H, Waki M, Tokura Y. TSLP Directly Interacts With Skin-Homing Th2 Cells Highly Expressing Its Receptor to Enhance IL-4 Production in Atopic Dermatitis. J Invest Dermatol (2015) 135 (12):3017-24. doi: 10.1038/jid.2015.318

13. Bao K, Reinhardt RL. The Differential Expression of IL-4 and IL-13 and Its Impact on Type-2 Immunity. Cytokine (2015) 75(1):25-37. doi: 10.1016/ j.cyto.2015.05.008

14. Nakayama T, Hirahara K, Onodera A, Endo Y, Hosokawa H, Shinoda K, et al. Th2 Cells in Health and Disease. Annu Rev Immunol (2017) 35:53-84. doi: 10.1146/annurev-immunol-051116-052350

15. Gieseck RL3rd, Wilson MS, Wynn TA. Type 2 Immunity in Tissue Repair and Fibrosis. Nat Rev Immunol (2018) 18(1):62-76. doi: 10.1038/nri.2017.90

16. Galli SJ, Tsai M. Ige and Mast Cells in Allergic Disease. Nat Med (2012) 18 (5):693-704. doi: 10.1038/nm.2755

17. Kanagaratham C, El Ansari YS, Lewis OL, Oettgen HC. Ige and IgG Antibodies as Regulators of Mast Cell and Basophil Functions in Food Allergy. Front Immunol (2020) 11:603050. doi: 10.3389/fimmu.2020.603050

18. Zen Y, Fujii T, Harada K, Kawano M, Yamada K, Takahira M, et al. Th2 and Regulatory Immune Reactions are Increased in Immunoglobulin G4-Related Sclerosing Pancreatitis and Cholangitis. Hepatology (2007) 45(6):1538-46. doi: 10.1002/hep.21697

19. Tanaka A, Moriyama M, Nakashima H, Miyake K, Hayashida JN, Maehara $\mathrm{T}$, et al. Th2 and Regulatory Immune Reactions Contribute to IgG4 Production and the Initiation of Mikulicz Disease. Arthritis Rheum (2012) 64(1):254-63. doi: 10.1002/art.33320

20. Wills-Karp M, Santeliz J, Karp CL. The Germless Theory of Allergic Disease: Revisiting the Hygiene Hypothesis. Nat Rev Immunol (2001) 1:69-75. doi: $10.1038 / 35095579$

21. Wambre E, Bajzik V, DeLong JH, O’Brien K, Nguyen QA, Speake C, et al. A Phenotypically and Functionally Distinct Human TH2 Cell Subpopulation is Associated With Allergic Disorders. Sci Transl Med (2017) 9(401): eaam9171. doi: 10.1126/scitranslmed.aam9171

22. Hsieh SC, Shen CY, Liao HT, Chen MH, Wu CH, Li KJ, et al. The Cellular and Molecular Bases of Allergy, Inflammation and Tissue Fibrosis in Patients With IgG-related Disease. Int J Mol Sci (2020) 21(14):5082. doi: 10.3390/ijms21145082

23. Akiyama M, Suzuki K, Yasuoka H, Kaneko Y, Yamaoka K, Takeuchi T. Follicular Helper T Cells in the Pathogenesis of IgG4-Related Disease. Rheumatol (Oxford) (2018) 57(2):236-45. doi: 10.1093/rheumatology/kex171

24. Kamisawa T, Zen Y, Pillai S, Stone JH. IgG4-related Disease. Lancet (2015) 385(9976):1460-71. doi: 10.1016/S0140-6736(14)60720-0

25. Della Torre E, Bozzalla-Cassione E, Sciorati C, Ruggiero E, Lanzillotta M, Bonfiglio S, et al. A CD8a-Subset of CD4+SLAMF7+ Cytotoxic T Cells is Expanded in Patients With IgG4-Related Disease and Decreases Following Glucorticoid Treatement. Arthritis Rheumatol (2018) 70:1133-43. doi: 10.1002/art.40469

26. Mattoo H, Mahajan VS, Maehara T, Desphande V, Della-Torre E, Wallace ZS, et al. Clonal Expansion of CD4+ Cytotoxic T Lymphocytes in Patients With IgG4-Related Disease. J Allergy Clin Immunol (2016) 138(3):825-38. doi: 10.1016/j.jaci.2015.12.1330

27. Maehara T, Mattoo H, Ohta M, Mahajan VS, Moriyama M, Yamauchi M, et al. Lesional CD4+ IFN-Gamma+ Cytotoxic T Lymphocytes in IgG4Related Dacryoadenitis and Sialoadenitis. Ann Rheum Dis (2017) 76(2):37785. doi: 10.1136/annrheumdis-2016-209139

28. Renzi PM, Turgeon JP, Marcotte JE, Drblik SP, Bérubé D, Gagnon MF, et al. Reduced Interferon-G Production in Infants With Bronchiolitis and Asthma. Am J Respir Crit Care Med (1999) 159:1417-22. doi: 10.1164/ ajrccm.159.5.9805080

29. Yao Y, Wang ZC, Yu D, Liu Z. Role of Allergen-Specific T-follicular Helper Cells in Immunotherapy. Curr Opin Allergy Clin Immunol (2018) 18(6):495501. doi: 10.1097/ACI.0000000000000480
30. Kamekura R, Takano K, Yamamoto M, Kawata K, Shigehara K, Jitsukawa S, et al. Cutting Edge: A Critical Role of Lesional T Follicular Helper Cells in the Pathogenesis of IgG4-Related Disease. J Immunol (2017) 199(8):2624-9. doi: 10.4049/jimmunol.1601507

31. Jeannin P, Lecoanet S, Delneste Y, Gauchat JF, Bonnefoy JY. Ige Versus IgG4 Production can be Differentially Regulated by IL-10. J Immunol (1998) 160 (7):3555-61.

32. Wood N, Bourque K, Donaldson DD, Collins M, Vercelli D, Goldman SJ, et al. Il-21 Effects on Human IgE Production in Response to IL-4 or IL-13. Cell Immunol (2004) 231:133-45. doi: 10.1016/j.cellimm.2005.01.001

33. Akiyama M, Yasuoka H, Yoshimoto K, Takeuchi T. Interleukin-4 Contributes to the Shift of Balance of IgG Subclasses Toward IgG4 in IgG4-related Disease. Cytokine (2018) 110:416-9. doi: 10.1016/j.cyto.2018.05.009

34. Moens L, Tangye SG. Cytokine-Mediated Regulation of Plasma Cell Generation: IL-21 Takes Center Stage. Front Immunol (2014) 5:65. doi: $10.3389 /$ fimmu. 2014.00065

35. Umehara H, Nakajima A, Nakamura T, Kawanami T, Tanaka M, Dong L, et al. IgG4-related Disease and Its Pathogenesis-Cross-Talk Between Innate and Acquired Immunity. Int Immunol (2014) 26(11):585-95. doi: 10.1093/ intimm/dxu074

36. Aalberse RC, Platts-Mills TA, Rispens T. The Developmental History of IgE and IgG4 Antibodies in Relation to Atopy, Eosinophilic Esophagitis, and the Modified TH2 Response. Curr Allergy Asthma Rep (2016) 16(6):45. doi: 10.1007/s11882-016-0621-x

37. Nutt SL, Hodgkin PD, Tarlinton DM, Corcoran LM. The Generation of Antibody-Secreting Plasma Cells. Nat Rev Immunol (2015) 15(3):160-71. doi: $10.1038 /$ nri3795

38. Mattoo H, Stone JH, Pillai S. Clonally Expanded Cytotoxic CD4+ T Cells and the Pathogenesis of IgG4-Related Disease. Autoimmunity (2017) 50 (1):19-24. doi: 10.1080/08916934.2017.1280029

39. Perugino CA, Stone JH. Treatment of IgG4-related Disease: Current and Future Approaches. Z Rheumatol (2016) 75(7):681-6. doi: 10.1007/s00393016-0142-y

40. Mattoo H, Mahajan VS, Della-Torre E, Sekigami Y, Mollie C, Wallace Z, et al. De Novo Oligoclonal Expansions of Circulating Plasmablasts in Active and Relapsing IgG4-related Disease. J Allergy Clin Immunol (2014) 134 (3):679-87. doi: 10.1016/j.jaci.2014.03.034

41. Dema B, Charles N, Pellefigues C, Ricks TK, Suzuki R, Jiang C, et al. Immunoglobulin E Plays an Immunoregulatory Role in Lupus. J Exp Med (2014) 211(11):2159-68. doi: 10.1084/jem.20140066

42. Hasni S, Gupta S, Davis M, Poncio E, Temesgen-Oyelakin Y, Joyal E, et al. Safety and Tolerability of Omalizumab, A Randomized Clinical Trial of Humanized Anti-Ige Monoclonal Antibody in Systemic Lupus Erythematosus (Stop Lupus). Arthritis Rheumatol (2019) 71(7):1135-40. doi: $10.1002 / a r t .40828$

43. Reuter S, Stassen M, Taube C. Mast Cells in Allergic Asthma and Beyond. Yonsei Med J (2010) 51(6):797-807. doi: 10.3349/ymj.2010.51.6.797

44. van de Veen W, Akdis M. Role of IgG4 in IgE-Mediated Allergic Responses. J Allergy Clin Immunol (2016) 138(5):1434-5. doi: 10.1016/jaci.2016.07.022

45. Caubet JC, Lin J, Ahrens B, Gimenez G, Bardina L, Niggemann B, et al. Natural Tolerance Development in Cow's Milk Allergic Children: IgE and IgG4 Epitope Binding. Allergy (2017) 72(11):1677-85. doi: 10.1111/all.13167

46. Zhang L, Guo L, Huang Y, Wang T, Shi X, Chang H, et al. Allergic Diseases, Immunoglobulin E, and Autoimmune Pancreatitis: A Retrospective Study of 22 Patients. Chin Med J (2014) 127:4104-9.

47. Platts-Mills T, Vaughan J, Squillace S, Woodfolk, Sporik R. Sensitisation, Asthma, and a Modified Th2 Response in Children Exposed to Cat Allergen: A Population-Based Cross-Sectional Study. Lancet (2001) 357(9258):752-6. doi: 10.1016/S0140-6736(00)04168-4

48. He JS, Subramanian S, Narang V, Srinivasan K, Saunders SP, Carbajo D, et al. IgG1 Memory B Cells Keep the Memory of IgE Responses. Nat Commun (2017) 8(1):641. doi: 10.1038/s41467-017-00723-0

49. Talay O, Yan D, Brightbill HD, Straney EEM, Zhou M, Ladi E, et al. IgE+ Memory Plasma Cells Generated Through a Germinal-Center Pathway. Nat Immunol (2012) 13:396-404. doi: 10.1038/ni.2256

50. Looney TJ, Lee JY, Roskin KM, Hoh RA, King J, Glanville J, et al. Human B Cell Isotype Switching Origins of Ige. J Allergy Clin Immunol (2016) 137 (2):579-86. doi: 10.1016/j.jaci.2015.07.014 
51. Lighaam LC, Vermeulen E, den Bleker T, Meijlink KJ, Aalberse RC, Barnes E, et al. Phenotypic Differences Between IgG4+ and IgG1+B Cells Point to Distinct Regulation of the IgG4 Response. J Allergy Clin Immunol (2014) 133 (1):267-70.e1-6. doi: 10.1016/j.jaci.2013.07.044

52. Abraham Soman N, Ashley L, John ST. Mast Cell-Orchestrated Immunity to Pathogens. Nat Rev Immunol (2010) 10(6):440-52. doi: 10.1038/nri2782

53. Nishida K, Gion Y, Takeuchi M, Tanaka T, Kataoka TR, Yoshino T. Mast Cells Exhibiting Strong Cytoplasmic Staining for IgE and High Affinity IgE Receptor are Increased in IgG4-Related Disease. Sci Rep (2018) 8(1):4656. doi: 10.1038/s41597-018-23043-9

54. Bradding P, Arthur G. Mast Cells in Asthma-State of the Art. Clin Exp Allergy (2016) 46(2):194-263. doi: 10.1111/cea.12675

55. Bradding P, Pejler G. The Controversial Role of Mast Cells in Fibrosis. Immunol Rev (2018) 282(1):198-231. doi: 10.1111/imr.12626

56. Zhu J. T Helper 2 (Th2) Cell Differentiation, Type2 Innate Lymphoid Cell (ILC2) Development and Regulation of Interleukin-4 (IL-4) and IL-13. Cytokine (2015) 75(1):14-24. doi: 10.1016/j.cyto.2015.05.010

57. Punnonen J, Aversa G, Cocks BG, McKenzie AN, Menon S, Zurawski G, et al. Interleukin 13 Induces Interleukin 4-Independent IgG4 and IgE Synthesis and CD23 Expression by Human B Cells. Proc Natl Acad Sci USA (1993) 90(8):3730-4. doi: 10.1073/pnas.90.8.3730

58. Finkelman FD, Boyce JA, Vercelli D, Rothenberg ME. Key Advances in Mechanisms of Asthma, Allergy, and Immunology in 2009. J Allergy Clin Immunol (2010) 125(2):312-8. doi: 10.1016/j.jaci.2009.12.936

59. Saunders SP, Ma EGM, Aranda CJ, Curotto de Lafaille MA. Non-Classical B Cell Memory of Allergic Ige Responses. Front Immunol (2019) 10:715. doi: 10.3389/fimmu.2019.00715

60. Yamamoto M, Takano KI, Kamekura R, Aochi S, Suzuki C, Ichimiya S, et al. Interleukin 5-Producing ST2+ Memory Th2 Cells in IgG4-Related Dacryoadenitis and Sialadenitis. Mod Rheumatol (2019) 29(5):856-60. doi: 10.1080/14397595.2018.1526357

61. Crawford A, Macleod M, Schumacher T, Corlett L, Gray D. Primary T Cell Expansion and Differentiation In Vivo Requires Antigen Presentation by B Cells. J Immunol (2006) 176(6):3498-506. doi: 10.4049/jimmunol.176.6.3498

62. Long H, Liao W, Wang L, Lu Q. A Player and Coordinator: The Versatile Roles of Eosinophils in the Immune System. Transfus Med Hemother (2016) 43(2):96-108. doi: 10.1159/000445215

63. Sokol CL, Medzhitov R. Emerging Functions of Basophils in Protective and Allergic Immune Responses. Mucosal Immunol (2010) 3(2):129-37. doi: $10.1038 / \mathrm{mi} .2009 .137$

64. Klion AD, Ackerman SJ, Bochner BS. Contributions of Eosinophils to Human Health and Disease. Annu Rev Pathol (2020) 15:1179-209. doi: 10.1146/annurev-pathmechdis-012419-032756

65. Zhang X, Zhang P, Li J, He Y, Fei Y, Peng L, et al. Different Clinical Patterns of IgG4-RD Patients With and Without Eosinophilia. Sci Rep (2019) 9 (1):16483. doi: 10.1038/s41598-019-52847-6

66. Huaux F, Liu T, McGarry B, Ullenbruch M, Xing Z, Phan SH. Eosinophils and $\mathrm{T}$ Lymphocytes Possess Distinct Roles in Bleomycin-Induced Lung Injury and Fibrosis. J Immunol (2003) 171(10):5470-81. doi: 10.4049/ jimmunol.171.10.5470

67. Watanabe T, Yamashita K, Sakurai T, Kudo M, Shiokawa M, Uza N. Toll-Like Receptor Activation in Basophils Contributes to the Development of IgG4-related Disease. J Gastroenterol (2013) 48(2):247-53. doi: 10.1007/s00535-012-0626-8

68. Yamamoto M, Takahashi H, Shinomura Y. Mechanisms and Assessment of IgG4-Related Disease: Lessons for the Rheumatologist. Nat Rev Rheumatol (2014) 10(3):148-59. doi: 10.1038/nrrheum.2013.183

69. Liu C, Zhang P, Zhang W. Immunological Mechanisms of IgG4-related Disease. J Transl Autoimmun (2020) 3:100047. doi: 10.1016/j.jtauto.2020.100047

70. Yang D, Han Z, Oppenheim JJ. Alarmins and Immunity. Immunol Rev (2017) 280(1):41-56. doi: 10.1111/imr.12577

71. Corren J, Ziegler SF. TSLP: From Allergy to Cancer. Nat Immunol (2019) 20 (12):1603-9. doi: 10.1038/s41590-019-0524-9

72. Yajima R, Takano K, Konno T, Kohno T, Kaneko Y, Kakuki T, et al. Mechanism of Fibrogenesis in Submandibular Glands in Patients With Igg4RD. J Mol Histol (2018) 49(6):577-87. doi: 10.1007/s10735-018-9796-x

73. Nickel R, Beck LA, Stellato C, Schleimer RP. Chemokines and Allergic Disease. J Allergy Clin Immunol (1999) 104(4Pt1):723-42. doi: 10.1016/ s0091-6749(99)70281-2
74. Mikhak Z, Fukui M, Farsidjani A, Medoff BD, Tager AM, Luster AD, et al. Contribution of CCR4 and CCR8 to Antigen-Specifc T(H)2 Cell Trafficking in Allergic Pulmonary Infammation. J Allergy Clin Immunol (2009) 123 (1):67-73. e3. doi: 10.1016/j.jaci.2008.09.049

75. Umeda M, Origuchi T, Kawashiri SY, Koga T, Ichinose K, Furukawa K, et al. Thymus and Activation-Regulated Chemokine as a Biomarker for IgG4related Disease. Sci Rep (2020) 10(1):6010. doi: 10.1038/s41598-020-62941-9

76. Gao P, Zhenzhong S, Lv X, Zhang J. Interleukin-35 in Asthma and its Potential as an Effective Therapeutic Agent. Mediators Inflamm (2017) 2017:5931865. doi: 10.1155/2017/5931865

77. Wong CK, Leung TF, Chu IM, Dong J, Lam YY, Lam CW. Aberrant Expression of Regulatory Cytokine IL-35 and Pattern Recognition Receptor NOD2 in Patients With Allergic Asthma. Inflammation (2015) 38(1):34860. doi: 10.1007/s10753-014-0038-4

78. Ito T, Tanaka T, Nakamaru K, Tomiyama T, Yamaguchi T, Ando Y, et al. Interleukin-35 Promotes the Differentiation of Regulatory $\mathrm{T}$ Cells and Suppresses Th2 Response in IgG4-Related Type 1 Autoimmune Pancreatitis. J Gastroenterol (2020) 55(8):789-99. doi: 10.1007/s00535-02001689-5

79. Zhang J, Lian M, Li B, Gao L, Tanaka T, You Z, et al. Interleukin-35 Promotes Th9 Cell Differentiation in IgG4-Related Disorders: Experimental Data and Review of the Literature. Clin Rev Allergy Immunol (2021) 60 (1):132-45. doi: 10.1007/s12016-020-08803-8

80. Soussi-Gounni A, Kontolemos M, Hamid Q. Role of IL-9 in the Pathophysiology of Allergic Disease. J Allergy Clin Immunol (2001) 107 (4):575-82. doi: 10.1067/mai.2001.114238

81. Terao C, Ota M, Iwasaki T, Shiokawa M, Kawaguchi S, Kuriyama K, et al. IgG4-related Disease in the Japanese Population: A Genome-Wide Association Study. Lancet Rheumatol (2019) 1(1):e14-22. doi: 10.1016/ S2665-9913(19)30006-2

82. Howell WM, Turner SJ, Hourihane JO, Dean TP, Warner JO. HLA Class II Drb1, DQB1 and DPB1 Genotypic Associations With Peanut Allergy: Evidence From a Family-Based and Case-Control Study. Clin Exp Allergy (1998) 28(2):156-62. doi: 10.1046/j.1365-2222.1998.00224.x

83. Wu J, Lin R, Huang J, Guan W, Oetting WS, Sriramarao P, et al. Functional Fcgamma Receptor Polymorphisms Are Associated With Human Allergy. PloS One (2014) 9(2):e89196. doi: 10.1371/journal.pone.0089196

84. Zen Y, Nakanuma Y. IgG4-related Disease: A Cross-Sectional Study of 114 Cases. Am J Surg Pathol (2010) 34(12):1812-9. doi: 10.1097/PAS. 0b013e3181f7266b

85. Masaki Y, Dong L, Kurose N, Kitagawa K, Morikawa Y, Yamaomoto M, et al. Proposal for a New Clinical Entity, IgG4-positive Multiorgan Lymphoproliferative Syndrome: Analysis of 64 Cases of IgG4-related Disorders. Ann Rheum Dis (2009) 68(8):1310-5. doi: 10.1136/ard.2008.089169

86. Baqir M, Garrity JA, Vassallo R, Witzig TE, Ryu JH. Asthma and Orbital Immunoglobulin G4-related Disease. Ann Allergy Asthma Immunol (2016) 116(4):313-6. doi: 10.1016/j.anai.2015.12.003

87. Lee YS, Cho HJ, Yoo HS, Shin YS, Park HS. A Case of IgG4-related Disease With Bronchial Asthma and Chronic Rhinosinusitis in Korea. J Korean Med Sci (2014) 29(4):599-603. doi: 10.3346/jkms.2014.29.4.599

88. London J, Martin A, Soussan M, Badelon I, Gille T, Uzunhan Y, et al. Adult Onset Athma and Periocular Xanthogranuloma (AAPOX), a Rare Entity With a Strong Link to IgG4-related Disease: An Observational Case Report Study. Med (Baltimore) (2015) 94(43):e1916. doi: 10.1097/MD. 0000000000001916

89. Pomponio G, Olivari D, Mattioli M, Angeletti A, Rossetti G, Goteri G, et al. Sustained Clinical Response After Single Course of Rituximab as First-Line Monotherapy in Adult-Onset Asthma and Periocular Xanthogranulomas Syndrome Associated With IgG4-Related Disease: A Case Report. Med (Baltimore) (2018) 97(26):e11143. doi: 10.1097/MD. 0000000000011143

90. Flament T, Marchand-Adam S, Gatault P, Dupin C, Diot P, Guilleminault L. What are the Characteristics of Asthma Patients With Elevated Serum IgG4 Levels? Respir Med (2016) 112:39-44. doi: 10.1016/j.rmed.2016.01.014

91. Skov M, Pandey JP, Pressler T, Høiby N, Koch C. Immunoglobulin Allotypes and IgG Subclass Antibody Response to Aspergillus Fumigatus in Cystic Fibrosis Patients. J Cyst Firbros (2004) 3(3):173-8. doi: 10.1016/ j.jcf.2004.05.048 
92. Gao Y, Zheng M, Cui L, Chen N, Wang YN, Zhan YT, et al. IgG4-related Disease: Association Between Chronic Rhino-Sinusitis and Systemic Symptoms. Eur Arch Otorhinolaryngol (2018) 275(8):2013-9. doi: 10.1007/ s00405-018-5013-5

93. Song BH, Baiyee D, Liang J. A Rare and Emerging Entity: Sinonasal IgG4related Sclerosing Disease. Allergy Rhinol (Providence) (2015) 6(3):151-7. doi: 10.2500/ar.2015.6.0136

94. Pace C, Ward S. A Rare Case of IgG4-related Sclerosing Disease of the Maxillary Sinus Associated With Bone Destruction. J Oral Maxillofac Surg (2010) 68(10):2591-3. doi: 10.1016/j.joms.2009.07.073

95. Inoue A, Wada K, Matsuura K, Osafune H, Ida Y, Kosakai A, et al. IgG4related Disease in the Sinonasal Cavity Accompanied by Intranasal Structure Loss. Auris Nasus Larynx (2016) 43(1):100-4. doi: 10.1016/j.anl.2015.05.005

96. Piao Y, Zhang Y, Yue C, Wang C, Zhang L. Immunoglobulin G4-related Chronic Rhinosinusitis: A Pitfall in the Differential Diagnosis of Granulomatosis With Polyangiitis, Rosai-Dorfman Disease, and Fungal Rhinosinusitis. Hum Pathol (2018) 73:82-8. doi: 10.1016/j.humpath. 2017.12.011

97. Ikeda R, Awataguchi T, Shoji F, Oshima T. A Case of Paranasal Sinus Lesions in IgG4-Related Sclerosing Disease. Otolaryngol Head Neck Surg (2010) 142(3):458-9. doi: 10.1016/j.otohns.2009.09.019

98. Vandjelovic ND, Humphreys IM. Immunoglobulin G4-related Sclerosing Disease of the Paranasal Sinuses: A Case Report and Literature Review. Allergy Rhinol (Providence) (2016) 7(2):85-9. doi: 10.2500/ar.2016.7.0154

99. Johal K, Welch K, Peters A. Immunoglobulin G4 Sinusitis in Association With Aspirin-Exacerbated Respiratory Disease. Am J Rhinol Allergy (2017) 31(5):302-4. doi: 10.2500/ajra.2017.31.4455

100. Lanham JG, Elkon KB, Pusey CD, Hughes GR. Systemic Vasculitis With Asthma and Eosinophilia: A Clinical Approach to the Churg Strauss Syndrome. Med (Baltimore) (1984) 63(2):65-81. doi: 10.1097/00005792198403000-00001

101. Yamamoto M, Takahashi H, Suzuki C, Tabeya T, Ohara M, Naishiro Y, et al. Analysis of Serum IgG Subclasses in Churg-Strauss syndrome-The Meaning of Elevated Serum Levels of Igg4. Intern Med (2010) 49(14):1365-70. doi: 10.2169/internalmedicine.49.3532

102. Vaglio A, Strehl JD, Manger B, Maritati F, Alberici F, Beyer C, et al. IgG4 Immune Response in Churg-Strauss Syndrome. Ann Rheum Dis (2012) 71 (3):390-3. doi: 10.1136/ard.2011.155382

103. Ayuzawa N, Ubara Y, Keiichi S, Masayuki Y, Hasegawa E, Hiramatsu E, et al. Churg-Strauss Syndrome With a Clinical Condition Similar to IgG4-Related Kidney Disease: A Case Report. Intern Med (2012) 51(10):1233-8. doi: 10.2169/internalmedicine.51.6074

104. Hanioka Y, Yamagami K, Yoshioka K, Nakamura T, Kishida M, Nakamura T, et al. Churg-Strauss Syndrome Concomitant With Chronic Symmetrical Dacryoadenitis Suggesting Mikulicz's Disease. Intern Med (2012) 51 (17):2457-61. doi: 10.2169/internalmedicine.51.7725

105. Kanani A, Betschel SD, Warrington R. Urticaria and Angioedema. Allergy Asthma Clin Immunol (2018) 14(Suppl 2):59. doi: 10.1186/s13223-018-0288-Z

106. Radonjic-Hoesli S, Hofmeier KS, Micaletto S, Schmid-Grendelmeier P, Bircher A, Simon D. Uritcaria and Angioedema: An Update on Classification and Pathogenesis. Clin Rev Allergy Immunol (2018) 54 (1):88-101. doi: 10.1007/s12016-017-8628-1

107. James C, Bernstein JA. Current and Future Therapies for the Treatment of Histamine-Induced Angioedema. Expert Opin Pharmacother (2017) 18 (3):253-62. doi: 10.1080/14656566.2017.1282461

108. McDuffie FC, Sams WMJr, Maldonado JE, Andreini PH, Conn DL, Samayoa EA. Hypocomplementemia With Cutaneous Vasculitis and Arthritis. Possible Immune Complex Syndrome. Mayo Clin Proc (1978) 48:340-8.

109. Buck A, Christensen J. Mccarty Morgan. Hypocomplementemic Urticarial Vasculitis Syndrome: A Case Report and Literature Review. J Clin Aesthet Dermatol (2012) 5(1):36-46.

110. Wakamatsu R, Watanabe H, Suzuki K, Suga N, Kitagawa W, Miura N, et al. Hypocomplementemic Urticarial Vasculitis Syndrome Is Associated With High Levels of Serum IgG4: A Clinical Manifestation That Mimics IgG4related Disease. Internal Med (2011) 50(10):1109-12. doi: 10.2169/ internalmedicine.50.4515

111. Takao M, Hamada T, Kaji T, Ikeda-Mizuno K, Takehara-Yasuhara C, Ichimura K, et al. Hypocomplementemic Urticarial Vasculitis Arising in a
Patient With Immunoglobulin G4-Related Disease. Int J Dermatol (2016) 55 (4):430-3. doi: 10.1111/ijd.12868

112. Pulendran B, Artis D. New Paradigms in Type 2 Immunity. Science (2012) 337(6093):431-5. doi: 10.1126/science.1221064

113. Muraki T, Hamano H, Ochi Y, Komatsu K, Komiyama Y, Arakura N, et al. Autoimmune Pancreatitis and Complement Activation System. Pancreas (2006) 32:16-21. doi: 10.1097/01.mp.0000188308.75043.e4

114. Pandey MK. Molecular Basis for Downregulation of C5a-mediated Inflammation by IgG1 Immune Complexes in Allergy and Asthma. Curr Allergy Asthma Rep (2013) 13(6):596-606. doi: 10.1007/s11882-013-0387-3

115. Shiokawa M, Kodama Y, Kuriyama K, Yoshimura K, Tomono T, Morita T, et al. Pathogenicity of IgG in Patients With IgG4-Related Disease. Gut (2016) 65(8):1322-32. doi: 10.1136/gutjnl-2015-310336

116. Ray A, Raundhal M, Oriss TB, Ray P, Wenzel SE. Current Concepts of Severe Asthma. J Clin Invest (2016) 126(7):2394-403. doi: 10.1172/JCI84144

117. Mullol J, Del Cuvillo A, Lockey RF. Rhinitis Phenotypes. J Allergy Clin Immunol Pract (2020) 8(5):1492-503. doi: 10.1016/j.jaip.2020.02.004

118. Ahmadi N, Brewer CC, Zalewski C, King KA, Butman JA, Plass N, et al. Cryopyrin-Associated Periodic Syndromes: Otolaryngologic and Audiologic Manifestations. Otolaryngol Head Neck Surg (2011) 145(2):295-302. doi: $10.1177 / 0194599811402296$

119. Schwartz DM, Kitakule MM, Dizon BL, Gutierrez-Huerta C, Blackstone SA, Burma AM, et al. Ann Rheum Dis (2021). doi: 10.1136/annrheumdis-2020219137

120. Quaranta M, Knapp B, Garzorz N, Mattii M, Pullabhatla V, Pennino D, et al. Intraindividual Genome Expression Analysis Reveals a Specific Molecular Signature of Psoriasis and Eczema. Sci Transl Med (2014) 6(244):244ra90. doi: 10.1126/scitranslmed.3008946

121. Kamisawa T, Anjki H, Egawa N, Kubota N. Allergic Manifestations in Autoimmune Pancreatitis. Eur J Gastroenterol Hepatol (2009) 21(10):11369. doi: 10.1097/meg.0b013e3283297417

122. Kawano M, Saeki T, Nakashima H, Nishi S, Yamaguchi Y, Hisano S, et al. Proposal for Diagnostic Criteria for IgG4-Related Kidney Disease. Clin Exp Nephrol (2011) 15(5):615-26. doi: 10.1007/s10157-011-0521-2

123. Della Torre E, Mattoo H, Mahajan VS, Carruthers M, Pillai S, Stone JH. Prevalence of Atopy, Eosinophilia, and IgE Elevation in IgG4-Related Disease. Allergy (2014) 69(2):269-72. doi: 10.1111/all.12320

124. Fernández-Codina A, Pinilla B, Pinal-Fernández I, López C, FraileRodríguez G, Fonseca-Aizpuru E, et al. Treatment and Outcomes in Patients With IgG4-Related Disease Using the IgG4 Responder Index. Joint Bone Spine (2018) 85(6):721-6. doi: 10.1016/j.jbspin.2018.01.014

125. Wallace ZS, Mattoo H, Mahajan VS, Kulikova M, Lu L, Deshpande V, et al. Predictors of Disease Relapse in IgG4-Related Disease Following Rituximab. Rheumatol (Oxford) (2016) 55(6):1000-8. doi: 10.1093/rheumatology/kev438

126. Carruthers MN, Topazian MD, Khosroshahi A, Witzing TE, Wallace ZS, Hart PA, et al. Rituximab for IgG4-Related Disease: A Prospective, OpenLabel Trial. Ann Rheum Dis (2015) 74(6):1171-7. doi: 10.1136/ annrheumdis-2014-206605

127. Paton DM. Dupilumab: Human Monoclonal Antibody Against IL-4Ra for Moderate to Severe Atopic Dermatitis. Drugs Today (Barc) (2017) 53(9):47787. doi: $10.1358 /$ dot.2017.53.9.2693150

128. Silverberg JI, Yosipovitch G, Simpson EL, Kim BS, Wu JJ, Echkert L, et al. Dupilumab Treatment Results in Early and Sustained Improvements in Itch in Adolescents and Adults With Moderate-to-Severe Atopic Dermatitis: Analysis of the Randomized Phase 3 Studies SOLO 1 \& SOLO 2, AD ADOL, and CHRONOS. J Am Acad Dermatol (2020) 82(6):1328-36. doi: 10.1016/j.jaad.2020.02.060

129. Yamamoto M, Yoshikawa N, Tanaka H. Efficacy of Dupilumab Reveals Therapeutic Target for IgG4-Related Disease: Simultaneous Control of Inflammation and Fibrosis. Ann Rheum Dis (2020). doi: 10.1136/ annrheumdis-2020-217076

130. Della-Torre E, Lanzillotta M, Yacoub MR. Dupilumab as a Potential SteroidSparing Treatment for IgG4-Related Disease. Ann Rheum Dis (2020). doi: 10.1136/annrheumdis-2020-216945

131. Grey A, Katelaris CH. Dupilumab in the Treatment of Asthma. Immunotherapy (2019) 11(10):859-72. doi: 10.2217/imt-2019-0008

132. Kasaian MT, Marquette K, Fish S, DeClercq C, Agostinelli R, Cook TA, et al. An IL-4/IL-13 Dual Antagonist Reduces Lung Inflammation, Airway 
Hyperresponsiveness, and IgE Production in Mice. Am J Respir Cell Mol Biol (2013) 49(1):37-46. doi: 10.1165/rcmb.2012-0500OC

133. Corren J, Lemanske RF, Hanania NA, Korenblat PE, Parsey MV, Arron JR, et al. Lebrikizumab Treatment in Adults With Asthma. N Engl J Med (2011) 365(12):1088-98. doi: 10.1056/NEJMoa1106469

134. Loh TY, Hsiao JL, Shi VY. Therapeutic Potential of Lebrikizumab in the Treatment of Atopic Dermatitis. J Asthma Allergy (2020) 13:109-14. doi: 10.2147/JAA.S211032

135. Maher TM, Costabel U, Glassberg MK, Kondoh Y, Ogura T, Scholand MB, et al. Phase 2 Trial to Assess Lebrikizumab in Patients With Idiopathich Pulmonary Fibrosis. Eur Respir J (2021) 57(2):1902442. doi: 10.1183/ 13993003.02442-2019

136. Edris A, De Feyter S, Maes T, Joos G, Lahousse LL. Monoclonal Antibodies in Type 2 Asthma: A Systematic Review and Network Meta-Analysis. Respir Res (2019) 20(1):179. doi: 10.1186/s12931-019-1138-3

137. Lee CG, Homer RJ, Zhu Z, Lanone S, Wang X, Koteliansky V, et al. Interleukin-13 Induces Tissue Fibrosis by Selectively Stimulating and Activating Transforming Growth Factor Beta (1). J Exp Med (2001) 194 (6):809-21. doi: 10.1084/jem.194.6.809

138. Wollenberg A, Howell MD, Guttman-Yassky E, Silverberg JI, Kell C, Ranade $\mathrm{K}$, et al. Treatment of Atopic Dermatitis With Tralokinumab, an anti-IL-13 Mab. J Allergy Clin Immunol (2019) 143(1):135-41. doi: 10.1016/ j.jaci.2018.05.029

139. Murray LA, Zhang H, Oak SR, Coelho AL, Herath A, Flaherty KR, et al. Targeting interleukin-13 With Tralokinumab Attenuates Lung Fibrosis and Epithelial Damage in a Humanized SCID Idiopathic Pulmonary Fibrosis Model. Am J Respir Cell Mol Biol (2014) May50(5):985-94. doi: 10.1165/ rcmb.2013-0342OC

140. Parker JM, Glaspole IN, Lancaster LH, Haddad TJ, She D, Roseti SL, et al. A Phase 2 Randomized Controlled Study of Tralokinumab in Subjects with Idiopathic Pulmonary Fibrosis. Am J Respir Crit Care Med (2018) 197(1):94103. doi: $10.1164 / \mathrm{rccm} .201704-0784 \mathrm{OC}$

141. Okayama Y, Matsumoto H, Odajima H, Takahagi S, Hide M, Okubo K. Roles of Omalizumab in Various Allergic Diseases. Allergol Int (2020) 69(2):16777. doi: 10.1016/j.alit.2020.01.004

142. El-Qutob D. Off Label Uses of Omalizumab. Clin Rev Allergy Immunol (2016) 50(1):84-96. doi: 10.1007/s12016-015-8490-y

143. Serrano-Candelas E, Martinez-Aranguren R, Valero A, Bartra J, Gastaminza G, Goikoetxea MJ, et al. Comparable Actions of Omalizumab on Mast Cells and Basophils. Clin Exp Allergy (2016) 46 (1):92-102. doi: $10.1111 /$ cea.12668

144. Clayton F, Fang JC, Gleich GJ, Lucendo AJ, Olalla JM, Vinson LA, et al. Eosinophilic Esophagitis in Adults Is Associated With IgG4 and Not Mediated by Ige. Gastroenterology (2014) 147(3):602-9. doi: 10.1053/ j.gastro.2014.05.036
145. Landolina NA, Levi-Schaffer F. Eosinophils as a Pharmacological Target for the Treatment of Allergic Diseases. Curr Opin Pharmacol (2014) 17:71-80. doi: 10.1016/j.coph.2014.07.014

146. Matucci A, Maggi E, Vutlaggio. Eosinophils, the IL-5/IL-5R $\alpha$ Axis, and the Biologic Effects of Benralizumab in Severe Asthma. Respir Med (2019) 160:105819. doi: 10.1016/j.rmed.2019.105819

147. Miyata $Y$, Inoue H, Homma T, Tanaka A, Sagara H. Efficacy of Benralizumab and Clinical Course of IgG4 on Eosinophilic Granulomatosis With Polyangiitis. J Investig Allergol Clin Immunol (2020). doi: 10.18176/jiaci.0648

148. Ortega HG, Liu MC, Pavord ID, Bruselle GG, FitzGerald JM, Chetta A, et al. Mepolizumab Treatment in Patients With Severe Eosinophilic Asthma. N Engl J Med (2014) 371(13):1198-207. doi: 10.1056/NEJMoa1403290

149. Vultaggio A, Nencini F, Bormioli S, Vibarelli E, Dies L, Rossi O, et al. LowDose Mepolizumab Effectiveness in Patients Suffering From Eosinophilic Granulomatosis With Polyangiitis. Allergy Asthma Immunol Res (2020) 12 (5):885-93. doi: 10.4168/aair.2020.12.5.885

150. Agache I, Beltran J, Akdis C, Akdis M, Canelo-Aybar C, Canonica GW, et al. Efficacy and Safety of Treatment With Biologicals (Benralizumab, Dupilumab, Mepolizumab, Omalizumab and Reslizumab) for Severe Eosinophilic Asthma. A Systematic Review for the EAACI GuidelinesRecommendations on the Use of Biological in Severe Asthma. Allergy (2020) 75(5):1023-42. doi: 10.1111/all.14221

151. Matera MG, Rogliani P, Calzetta, Cazzola M. Tslp Inhibitors for Asthma: Current Status and Future Prospects. Drugs (2020) 80(5):449-58. doi: $10.1007 /$ s40265-020-01273-4

152. Corren J, Wheatley L, Sanda S, Larson D, Qin T, Avila P, et al. Effects of Combined Treatment With Cat Allergen Immunotherapy and Tezepelumab on Nasal Allergen Challenge. J Allergy Clin Immunol (2020) 145(2):AB336. doi: 10.1016/j.jaci.2019.12.063

Conflict of Interest: TM has received consulting fees from Cugene, Kiniksa, Miro Bio, and QiLu Pharmaceuticals, has an ownership share in Amdax, and has received research funding from Gilead Sciences.

The remaining authors declare that the research was conducted in the absence of any commercial or financial relationships that could be construed as a potential conflict of interest.

Copyright (@) 2021 Michailidou, Schwartz, Mustelin and Hughes. This is an open-access article distributed under the terms of the Creative Commons Attribution License (CC BY). The use, distribution or reproduction in other forums is permitted, provided the original author(s) and the copyright owner(s) are credited and that the original publication in this journal is cited, in accordance with accepted academic practice. No use, distribution or reproduction is permitted which does not comply with these terms. 